\title{
A Virtual Geographic Environment for Debris Flow Risk Analysis in Residential Areas
}

\author{
Lingzhi Yin ${ }^{1}$, Jun Zhu ${ }^{1}$, , Yi Li ${ }^{2}$, Chao Zeng ${ }^{3}$, Qing Zhu ${ }^{1}$, Hua Qi ${ }^{1}$, Mingwei Liu ${ }^{1}$, Weilian Li ${ }^{1}$, \\ Zhenyu Cao ${ }^{3}$, Weijun Yang ${ }^{4}$ and Pengcheng Zhang ${ }^{4}$ \\ 1 Faculty of Geosciences and Environmental Engineering, Southwest Jiaotong University, \\ Chengdu 611756, China; Linzyhn@163.com (L.Y.); zhuq66@263.net (Q.Z.); qi-3dgis@126.com (H.Q.); \\ liumingwei@my.swjtu.edu.cn (M.L.); vgewilliam@163.com (W.L.) \\ 2 State Key Laboratory of Remote Sensing Science, Institute of Remote Sensing and Digital Earth, \\ Chinese Academy of Sciences, Beijing 100101, China; liyi@radi.ac.cn \\ 3 Sichuan Geomatics Center, Chengdu 610041, China; zeng3chao@163.com (C.Z.); scgisczy@163.com (Z.C.) \\ 4 Guangzhou Urban Planning \& Design Survey Research Institute, Guangzhou 510060, China; \\ fazeyang@gmail.com (W.Y.); guangzhou2000@126.com (P.Z.) \\ * Correspondence: zhujun@swjtu.edu.cn; Tel.: +86-130-8442-6186
}

Received: 9 October 2017; Accepted: 20 November 2017; Published: 22 November 2017

\begin{abstract}
Emergency risk assessment of debris flows in residential areas is of great significance for disaster prevention and reduction, but the assessment has disadvantages, such as a low numerical simulation efficiency and poor capabilities of risk assessment and geographic knowledge sharing. Thus, this paper focuses on the construction of a VGE (virtual geographic environment) system that provides an efficient tool to support the rapid risk analysis of debris flow disasters. The numerical simulation, risk analysis, and 3D (three-dimensional) dynamic visualization of debris flow disasters were tightly integrated into the VGE system. Key technologies, including quantitative risk assessment, multiscale parallel optimization, and visual representation of disaster information, were discussed in detail. The Qipan gully in Wenchuan County, Sichuan Province, China, was selected as the case area, and a prototype system was developed. According to the multiscale parallel optimization experiments, a suitable scale was chosen for the numerical simulation of debris flow disasters. The computational efficiency of one simulation step was $5 \mathrm{~ms}$ (milliseconds), and the rendering efficiency was approximately $40 \mathrm{fps}$ (frames per second). Information about the risk area, risk population, and risk roads under different conditions can be quickly obtained. The experimental results show that our approach can support real-time interactive analyses and can be used to share and publish geographic knowledge.
\end{abstract}

Keywords: virtual geographic environment; debris flow disaster; multiscale parallel optimization; real-time interaction; emergency analysis

\section{Introduction}

A debris flow is a typical geomorphic spatiotemporal process with hazard potential in mountainous areas and is trigged by intense rainfalls with landslides [1-3]. Debris flows create hazard risks, including human injury and death, property losses, social instability, and environmental destruction, and hinder the sustainable development of the economy in mountainous areas [4]. For example, the debris flow disasters that occurred in Zhouqu County on 7 August 2010, in Wenchuan County on 11 July 2013, and in Jiuzhaigou County on 25 July 2016, all resulted in damaged houses, traffic disruptions, a large number of casualties, and huge economic losses. Therefore, it is important to implement a rapid risk analysis of debris flow disasters in residential areas that can provide accurate disaster information. The disaster information consists of two parts: the disaster severity 
information and the disaster damage information. The disaster severity information includes the arrival time, inundated area, flow depth, and flow velocity. The disaster damage information includes the population and roads at risk. Such disaster information can provide scientific support for emergency rescue response and is of considerable significance for debris flow disaster prevention and reduction [5-7].

Risk assessment of debris flow disasters plays an important role in the analysis of the disaster area, risk degree, and disaster loss [8,9]. Most of the existing risk assessment methods are based on the relevant factor theory [10]. Assessment factors, such as the catchment area, relative elevation, rainfall intensity, and debris flow density, are used to construct the risk assessment function, and these assessment factors can be obtained from either a statistical analysis of the historical data and monitoring data that describe the occurrence of debris flow disasters or an interpretation of RS (remote sensing) images [11,12]. Although these methods can be used to quickly evaluate the risk of the debris flow disaster, the selection of the risk assessment factors and weight assignments, as well as the accuracy of the evaluation results are dependent on the experience of experts, and these methods can only be used to quantify the debris flow risk level for a whole gully $[10,13,14]$. Numerical simulation methods can quantitatively analyze the development process and the results of debris flow disasters in various conditions. Thus, many researchers have applied numerical simulation methods to the risk assessment of debris flow disasters $[7,9,15,16]$. However, the above numerical simulations are separated from the risk assessment analyses. Because the simulation results have to be imported into some professional software (e.g., ArcGIS) for a spatial analysis, this process requires a long time to obtain risk assessment results.

Currently, researchers mainly use GIS (Geographic Information Science)-supported numerical equations to construct a combination of one- and two-dimensional models for the simulation and analysis of a debris flow routing process $[17,18]$. However, in this field of research, most GIS software packages mainly use the CPU (central processing unit) serial computing mode to simulate the debris flow routing process, which results in a very long calculation time $[19,20]$. The calculation efficiency will be sharply reduced if high-resolution DEM (digital elevation model) data is used for high-resolution simulations. Therefore, to eliminate the limitation of computing power, it is necessary to introduce the parallel computing mode to the numerical simulation of debris flow disasters [21]. There have been some studies on numerical simulations of debris flow disasters that are based on parallel computing, including distributed computing based on sockets [22], parallel computing based on the CUDA (compute unified device architecture) platform [23,24], and multicore parallel computing based on OpenMP [25]. The method of multicore parallel computing based on OpenMP has the advantages of simplicity, portability, flexibility, and cross-platform capability [26]. However, to ensure the accuracy of the debris flow simulation, the above researches usually use high-resolution grid cell data for parallel computing, often leading to a low computational efficiency. Therefore, it is critical to determine how to quickly and accurately obtain disaster information, such as the flow depth, flow velocity, and inundated area.

Abundant complex disaster information can be obtained through a numerical simulation and risk assessment of debris flow disasters. However, it is difficult for such disaster information to effectively support multisensory spatial cognition, communication of multilevel geographic knowledge, and abstract representation and analysis beyond reality [27]. A VGE (virtual geographic environment) can be used for multidimensional abstract representations of the real world, multimodal visualizations with multiple viewpoints and multiple details, and analytical understandings [28]. Users can observe a geographic phenomenon and its evolution process through a 3D (three-dimensional) virtual geographic space $[28,29]$. At present, a VGE has been widely used in multiple fields, such as air pollution diffusion, dam-break flooding, and digital city modelling, to express and share geographic knowledge [30-32]. However, it has not been applied in the field of emergency analysis of debris flow disasters.

Furthermore, most of the existing 3D visualization platforms are compatible only when installed with plug-ins or additional software, and thus, it is difficult to achieve cross-platform compatibility, 
real-time updating, and multiuser terminal versatility [33]. However, the 3D, dynamic visualization of debris flow disasters in an emergency situation has higher cross-platform, real-time, and user experience requirements for the visualization platform. With the development of HTML5 and WebGL technologies, users can browse and observe $3 \mathrm{D}$, dynamic scenes in a browser without plug-ins. Currently, these technologies are supported by most browsers, such as Firefox, Chrome, and Apple Safari. Cesium is an open-source JavaScript library for world-class 3D globes and maps that are based on HTML5 and WebGL technologies. This paper will use Cesium to implement the 3D visualization of debris flow disasters.

Based on high-performance computing and WebGL technologies, our research goal is to integrate the simulation, analysis and visualization into a VGE framework, providing a tool for the rapid analysis of debris flow disasters in residential areas. Key technologies, including multiscale parallel optimization, quantitative risk assessment, and visual representation of disaster information, are discussed in detail. All of these efforts aim to solve the following problems: low numerical simulation efficiency, poor risk assessment capability, and difficulty in geographic knowledge sharing. The remainder of this paper is organized as follows: Section 2 shows the methods of the rapid risk analysis of the debris flow disaster, Section 3 describes the development of a prototype system and the implementation of the rudimentary experimentation, and Section 4 provides a conclusion and a brief discussion of further researches.

\section{Methods}

\subsection{Overall Framework}

The overall framework of the VGE is shown in Figure 1. It is divided into four layers: a basic data layer, a service layer, a presentation layer, and a user layer. The basic data layer provides abundant data resources to support the VGE system. The service layer is the core of the whole system. Based on the methods of simulation, risk assessment, and spatial analysis, the service layer can provide a professional service for the rapid simulation and interactive analysis to obtain disaster information. The presentation layer supports the multidimensional perception of the virtual geographic scene. It can improve the spatial cognitive efficiency for a debris flow disaster. The user layer is directly oriented toward the end user. Users can set the simulation parameters of a debris flow disaster routing process through an interactive interface and can perform a series of operations, such as querying and interactive analysis, on the simulation results.

\subsection{Multiscale Parallel Optimization}

Numerical simulation is an effective method to reproduce the recurrence and redevelopment of debris flows and can reflect the dynamic routing process and the spatial distribution of the flow velocity and flow depth of the debris flow in the affected area [34]. The particle model is used to simulate the debris flow disaster routing process in this paper. The particle model was proposed by Wang et al., and was based on the Lagrangian-Euler numerical method [35]. The particle model regards debris flow masses as multiple small particles, and each particle has the same size and shape. On this basis, Hu et al. used the forward difference method to calculate the flow velocity and the displacement of each particle at each time interval [10]. Then, the debris flow movement on alluvial fans can be approximately described by the movement of a large number of particles. Presently, this method has been used to simulate and analyze the debris flow disaster routing process $[7,36]$.

Due to the real-time interactive analysis in the VGE, the computational efficiency of numerical simulations needs to improve as soon as possible. According to the $3 \mathrm{D}$ visualization rendering efficiency requirements (no less than 25 frames per second), one simulation step should be completed within $40 \mathrm{~ms}[37,38]$. The data with different grid cell sizes has a considerable effect on the efficiency and accuracy of the simulation and, consequently, on the spatial analysis and visualization of debris flow disasters. Thus, it is better to select data with different grid cell sizes when a parallel simulation 
study of a debris flow disaster is to be performed. To meet the rapid simulation and visual analysis requirements of a debris flow disaster in an emergency situation, an appropriate grid cell size is selected on the premise of ensuring the accuracy of a debris flow disaster numerical simulation. We do not change the model itself. In this paper, we use a parallel computing technology and select appropriate grid cell sizes to improve the computational efficiency.

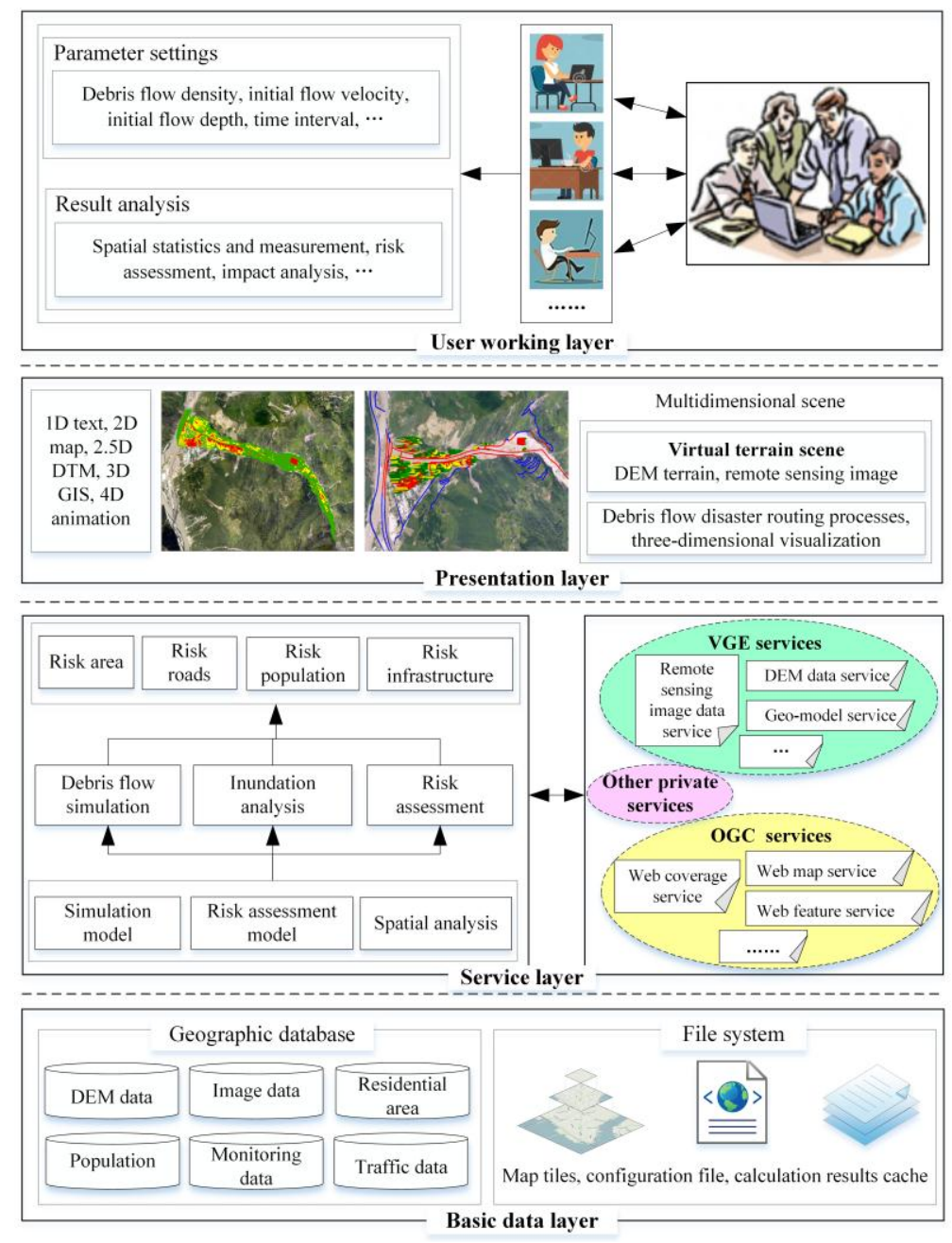

Figure 1. Overall framework.

The OpenMP framework was used to implement the parallel optimization of simulations with multiple grid cell sizes, as shown in Figure 2. First, the data, including the DEM, roughness coefficient, breach coordinates, particle ratio, peak flow, and initial flow depth are initialized. Second, the model based on CPU serial computing is divided into serial computing and parallel computing parts. The serial computing part is the main thread, including the calculations of the discharge at the breach, flow velocity, initial position and flow depth. The parallel computing mainly involves mapping the computing-intense update of particles for multithreading, including the flow velocity in the $\mathrm{x}$ direction and $\mathrm{y}$ direction, the displacement in the $\mathrm{x}$ direction and $\mathrm{y}$ direction, and the current time. Finally, after the completion of thread synchronization, the number of particles in each grid cell is calculated according to the new flow velocities, positions, and coordinates of the particles in the main thread. Then, the flow depth, the flow velocity, and the inundated area in each grid cell can be calculated through dispatching multiple threads at each time interval and then used to update the particle state values for the next time interval. Therefore, these calculation results can be used to dynamically analyze and visualize the debris flow disaster information. 

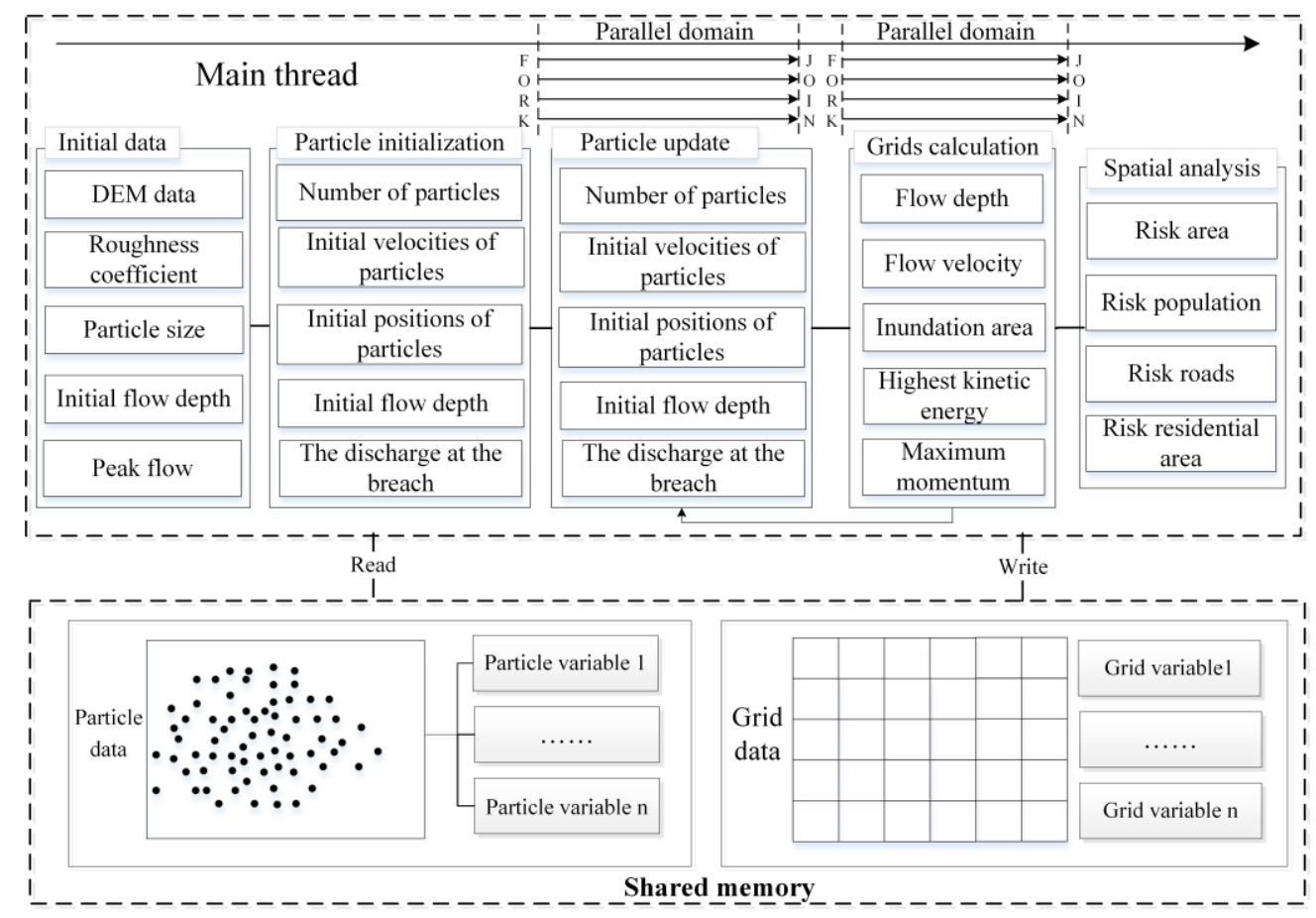

Figure 2. Multiscale parallel optimization based on the OpenMP framework.

\subsection{Quantitative Risk Assessment}

The risk assessment of debris flow disasters includes a comprehensive analysis of hazard and vulnerability [7]. Hazard assessment and vulnerability assessment are designed to estimate the damage capability of the debris flow and the losses that are suffered by risk objects, which are of considerable significance for disaster prevention and emergency response [39]. Damages from the debris flow are caused by the impact and silt effects. The flow velocity is the key parameter to determine the impact effect, and the flow depth reflects the deposition of the debris flow. Losses that are caused by a debris flow disaster mainly occur in the disaster inundated area and involve the damage degree and comprehensive value of the risk objects [36]. A quantitative risk assessment method for debris flow disasters is designed in this paper, as shown in Figure 3.

First, the quantitative risk assessment method is tightly integrated into the VGE framework. The numerical simulation of the debris flow disaster can be implemented after the parameters are set. Then, the disaster information, such as the flow depth, flow velocity, inundated area, and maximum flow depth of each grid cell, can be obtained. Second, after this disaster information is combined with the risk assessment model proposed by Zou et al. [36], the hazard value and vulnerability value of each grid cell can be obtained. In addition, these values can be divided into three levels, namely, low, medium, and high grades, and are obtained using the standard deviation method. Finally, integrated with the thematic data, including roads, residential areas and public facilities, the disaster information, such as risk area, risk roads, risk population, and risk infrastructure at different risk levels, is calculated individually by an overlay analysis. 


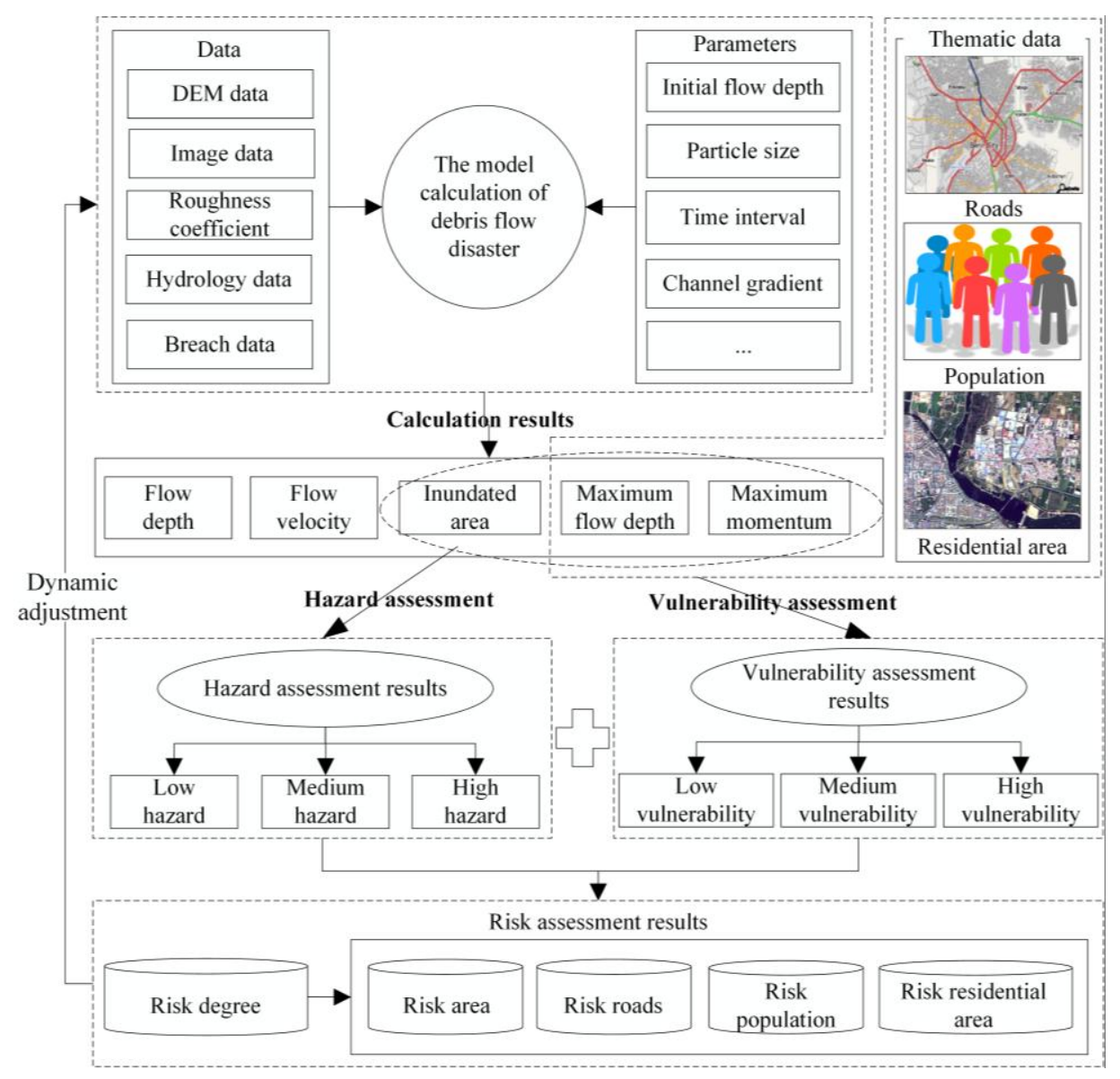

Figure 3. Quantitative risk assessment of debris flow disasters.

\subsection{Real-Time Visualization of Disaster Information}

A virtual geographic scene, which includes the virtual terrain, simulation results data, and thematic information, can be used to better understand and analyze debris flow disasters. Determining how to render these data in real time is very important for the interactive analysis of debris flow disasters.

First, local data and online data are the main data resources with which the virtual terrain scenes of debris flow disasters are constructed. The local data includes high-resolution RS data and DEM data, and these data are organized into a local cache based on a pyramid model using leveling and block processing. Then, these data are loaded and rendered according to the LOD (level of detail) requirements of the users. The online data includes a large number of high-resolution global satellite images and a large amount of map data and rough elevation data. The system can support multiple map data services such as WMS (web map service), WCS (web coverage service), and TMS (tiled map service) to obtain and parse these online data and then load and render them in real time. It can also support 3D visualization and browsing of a virtual earth with different resolutions.

Second, the simulation results of the debris flow disasters are stored in a two-dimensional array of the grid cell units. Each grid cell at different times contains data on the flow depth, elevation, and plane coordinates, which can support the rendering of the debris flow scenes. Because some grid cell states may be not included, there are many "invalid" data points in the array. Thus, to reduce the amount of data, only grid cells with flow depth data are extracted from the two-dimensional array, organized into a triangular network structure, and later parsed and rendered. The visualization color of the debris flow adopts a gray color scheme, which conforms to the public's perception. Different flow depths are visualized by different colors through hierarchical mapping, as shown in Figure 4a. 
Finally, thematic data, including roads, residential areas, and public facilities, is loaded as vector layers, which are used for risk assessment and spatial analysis of debris flow disasters. The risk area and risk population can be obtained through overlay analysis of the inundated area. The disaster degree can be determined through the risk assessment model. The color scheme of a risk map can be partly based on the combination of an early warning color system and the extension of an early warning color system [40], as shown in Figure 4b. Users can obtain disaster information, such as the disaster degree, risk roads, and risk population in the debris flow disaster routing process through an interactive query. All of the efforts aim at real-time visualization and interactive operation of disaster information.

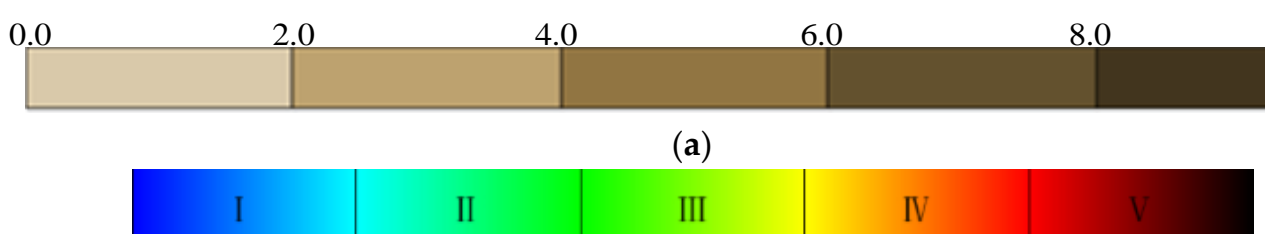

(b)

Figure 4. Visualization color design: (a) real-time flow depth and color mapping and (b) color grade designed in the risk map.

\section{Results and Analysis}

\subsection{Case Area}

The Qipan gully $\left(30^{\circ} 45^{\prime}-31^{\circ} 43^{\prime} \mathrm{N}, 102^{\circ} 51^{\prime}-103^{\circ} 44^{\prime} \mathrm{E}\right)$ is approximately $5 \mathrm{~km}$ southwest of Wenchuan County, which is located in the southeast of Sichuan Province, China (Figure 5). The mainstream of the Qipan gully is $15.1 \mathrm{~km}$ long and is the first tributary of the Minjiang River. Its drainage basin covers an area of $54.2 \mathrm{~km}^{2}$ and has an elevation ranging from $1320 \mathrm{~m}$ to $4360 \mathrm{~m}$. Because of a heavy rainfall from the night of 7-11 July 2013, the Qipan gully suffered a large debris flow disaster [41].

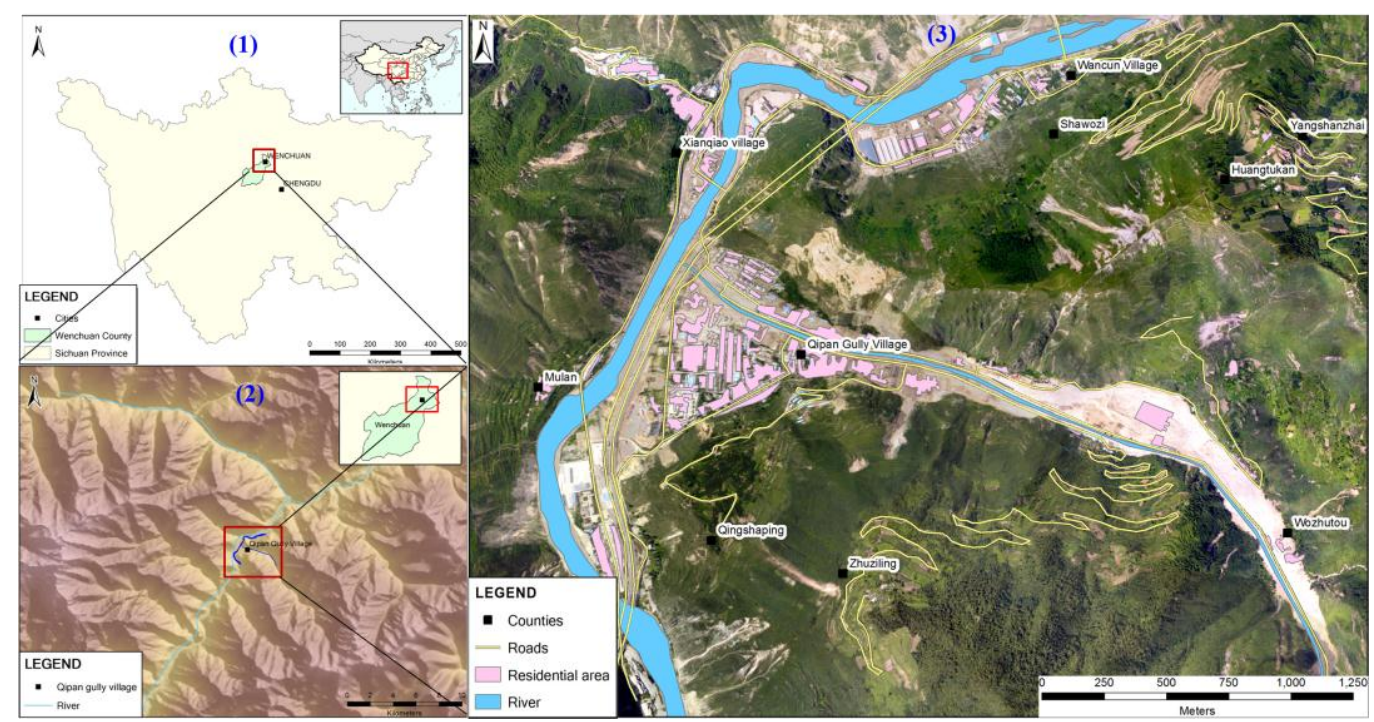

Figure 5. Case area. 


\subsection{Prototype System Development}

The simulation of the debris flow routing process in this paper is carried out by using C++ language and OpenMP parallel computing framework. The 3D scene of the debris flow disaster is constructed based on Cesium. The vector data in the disaster area is stored in the PostGIS spatial database and is published by the GIS server GeoServer as a WFS (web feature service) under the OGC (open geospatial consortium) standard. After being invoked by the system, the service can be loaded and parsed. This system includes four functions. First, it can integrate the online map data, which provides basic geographic information services. Second, it can provide a basic spatial analysis function. Third, it can support rapid simulation and risk assessment of debris flow disasters. Fourth, it can query the debris flow disaster information in real time. At present, the numerical simulation of debris flow disasters is oriented to expert users, and other functions of visualization and spatial analysis are for all of the users. The simulation analysis process is shown below. A visual interface is first provided for expert users to set the simulation parameters and start the simulation calculations. Then, a series of simulation results are generated automatically, and the disaster information, such as the maximum flow depths, maximum flow velocities, and inundated area can be obtained. Moreover, the risk population, risk roads, and risk residential area can be obtained through an overlay analysis of the thematic data. All of these data are automatically converted to the JSON (JavaScript object notation) format and are deployed as visual services. Finally, public users can interactively query and browse this disaster information on the client.

\subsection{Simulation Optimization Analysis}

To compare the computational efficiency under different situations, the DEM data is resampled to generate different grid cell sizes for analysis experiments. When the grid cell size is $40 \mathrm{~m}$, the debris flow model cannot run normally. Thus, the original terrain with $5 \mathrm{~m}$ spatial resolution is resampled to several typical sizes, such as $10 \mathrm{~m}, 20 \mathrm{~m}$, and $30 \mathrm{~m}$. The simulation experiments on the debris flow disaster routing processes are carried out by using CPU serial computing and multicore parallel computing based on the OpenMP framework; then, the accuracy of the simulation results from grids with different cell sizes can be compared.

The actual inundated area of the debris flow disaster is extracted from the post-disaster UAV (unmanned aerial vehicle) image, and the inundated area is approximately $657,316 \mathrm{~m}^{2}$. When the grid cell sizes are $5 \mathrm{~m}, 10 \mathrm{~m}, 20 \mathrm{~m}$, and $30 \mathrm{~m}$, the simulated inundated areas are $635,125 \mathrm{~m}^{2}, 712,600 \mathrm{~m}^{2}$, $699,600 \mathrm{~m}^{2}$, and $656,100 \mathrm{~m}^{2}$, respectively. The simulation results are quite similar to the measured results of the actual debris flow.

According to the field survey data of Zeng [42], flow velocities have been obtained at 11 cross sections in the Qipan gully. The maximum flow velocities of cross sections under different grid cell sizes are shown in Table 1, and the spatial distribution of the maximum flow velocities under different grid cell sizes is shown in Figure 6. When the grid cell sizes are $5 \mathrm{~m}, 10 \mathrm{~m}$, and $20 \mathrm{~m}$, the simulated flow velocities are consistent with the variation trend in the actual flow velocities. When the grid cell size is $30 \mathrm{~m}$, then the simulated flow velocities have larger errors. 
Table 1. Maximum flow velocities of cross sections under different grid cell sizes.

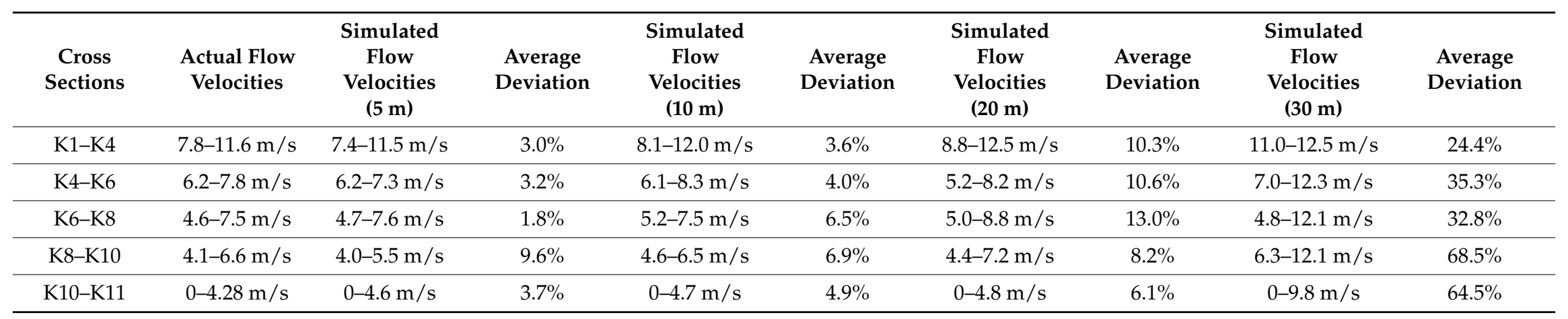




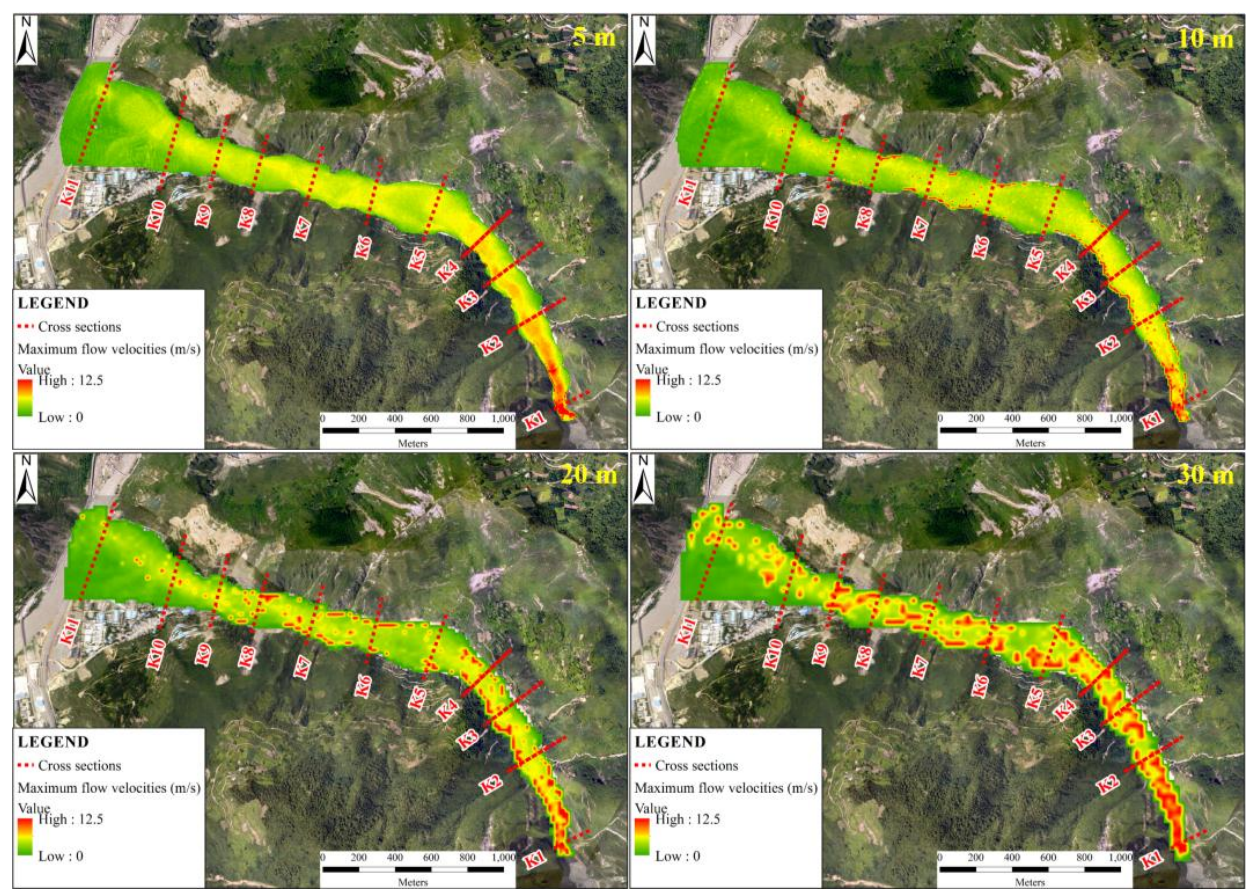

Figure 6. Spatial distribution of the maximum flow velocities under different grid cell sizes.

The actual flow depths of four reference points in the Qipan gully have been obtained by way of field investigation. The maximum flow depths of the reference points under different grid cell sizes are shown in Table 2, and the spatial distribution of the maximum flow depths under different grid cell sizes are shown in Figure 7. When the grid cell sizes are $5 \mathrm{~m}, 10 \mathrm{~m}$, and $20 \mathrm{~m}$, the simulation results are approximately the same as the actual flow depth. However, when the grid cell size is $30 \mathrm{~m}$, the simulated flow depths have larger errors.

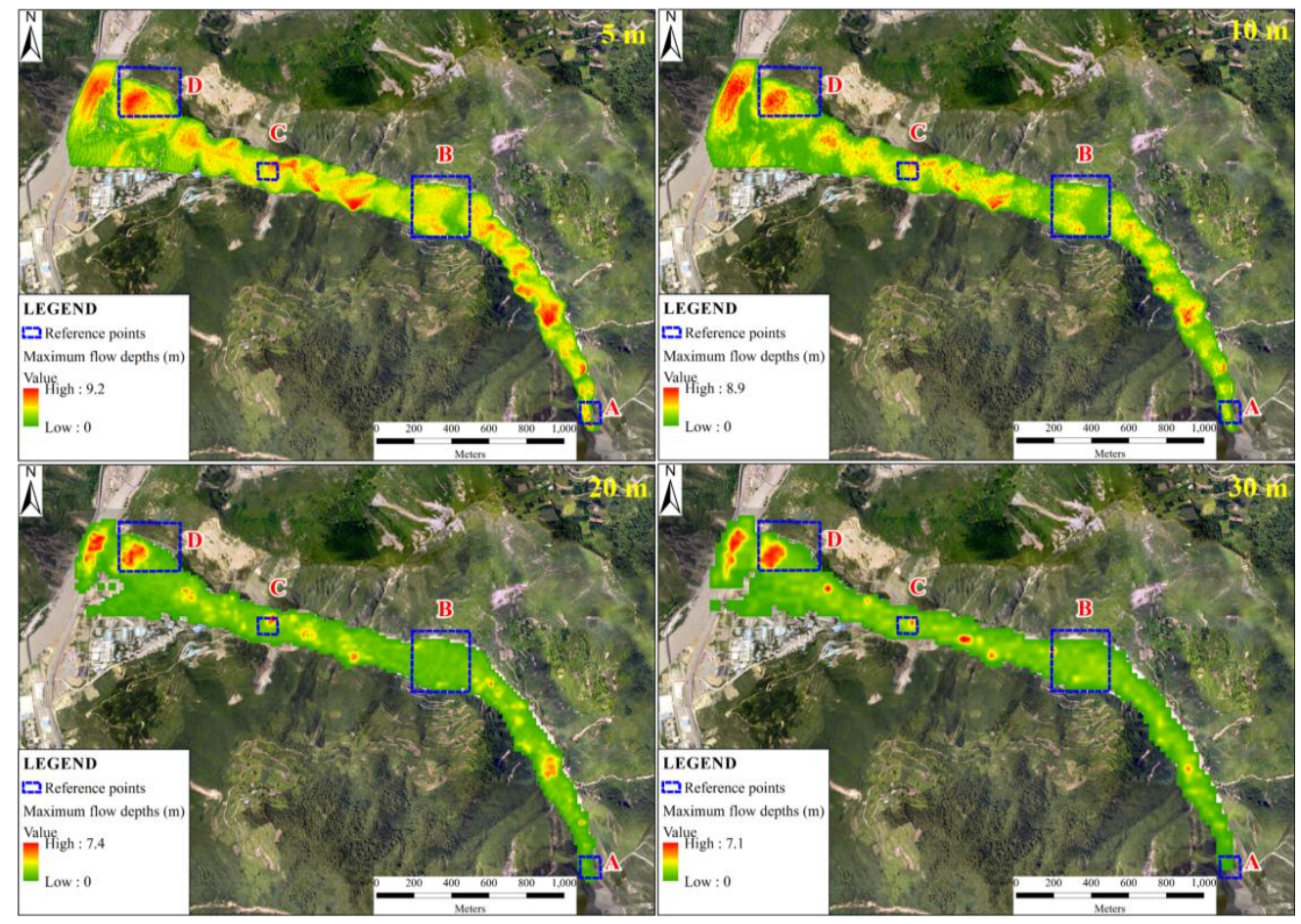

Figure 7. Spatial distribution of the maximum flow depths under different grid cell sizes. 
Table 2. Maximum flow depths of the reference points under different grid cell sizes.

\begin{tabular}{|c|c|c|c|c|c|c|c|c|c|}
\hline $\begin{array}{l}\text { Reference } \\
\text { Points }\end{array}$ & $\begin{array}{c}\text { Actual } \\
\text { Flow } \\
\text { Depths }\end{array}$ & $\begin{array}{l}\text { Simulated } \\
\text { Flow } \\
\text { Depths } \\
(5 \mathrm{~m})\end{array}$ & $\begin{array}{l}\text { Average } \\
\text { Deviation }\end{array}$ & $\begin{array}{l}\text { Simulated } \\
\text { Flow } \\
\text { Depths } \\
(10 \mathrm{~m})\end{array}$ & $\begin{array}{l}\text { Average } \\
\text { Deviation }\end{array}$ & $\begin{array}{l}\text { Simulated } \\
\text { Flow } \\
\text { Depths } \\
(20 \mathrm{~m})\end{array}$ & $\begin{array}{l}\text { Average } \\
\text { Deviation }\end{array}$ & $\begin{array}{l}\text { Simulated } \\
\text { Flow } \\
\text { Depths } \\
(30 \mathrm{~m})\end{array}$ & $\begin{array}{l}\text { Average } \\
\text { Deviation }\end{array}$ \\
\hline $\mathrm{A}$ & $5-8 \mathrm{~m}$ & $5.3-7.7 \mathrm{~m}$ & $4.9 \%$ & $5.2-7.2 \mathrm{~m}$ & $7.0 \%$ & $4.2-7.1 \mathrm{~m}$ & $13.6 \%$ & $1.4-4.2 \mathrm{~m}$ & $59.8 \%$ \\
\hline B & $2-4 \mathrm{~m}$ & $2.2-4.5 \mathrm{~m}$ & $11.3 \%$ & $1.8-4.6 \mathrm{~m}$ & $12.5 \%$ & $1.7-3.7 \mathrm{~m}$ & $15.0 \%$ & $1.5-2.5 \mathrm{~m}$ & $31.3 \%$ \\
\hline $\mathrm{C}$ & $4-6 \mathrm{~m}$ & $3.3-5.9 \mathrm{~m}$ & $9.6 \%$ & $3.7-6.5 \mathrm{~m}$ & $7.9 \%$ & $3.6-6.5 \mathrm{~m}$ & $9.2 \%$ & $1.2-2.3 \mathrm{~m}$ & $65.8 \%$ \\
\hline
\end{tabular}

To analyze the parallel computing performance, the multicore parallel computing time is recorded separately from the CPU computing time, as shown in Table 3. When the grid cell size is $5 \mathrm{~m}$, one simulation step is completed in approximately $50 \mathrm{~ms}$, which cannot meet the need of real-time interactive simulations. When the grid cell size is $10 \mathrm{~m}$, one simulation step is completed in approximately $15 \mathrm{~ms}$, which can meet the need of real-time interactive simulations. In fact, since the time of the data reading and writing occupies a large proportion as compared to the calculation time, the speedup ratio will decrease with the increase in the grid cell sizes. Furthermore, we can use different grid cell sizes and different computing modes together to analyze the computational performance. According to the above accuracy analysis results, we can select different grid cell sizes to simulate debris flow disasters. When the grid cell size is $5 \mathrm{~m}$, the CPU computing time is $43.07 \mathrm{~min}$. When the grid cell size is $20 \mathrm{~m}$, the parallel computing time is $0.29 \mathrm{~min}$. The maximum speedup ratio is approximately 148 . Thus, the multiscale parallel optimization can greatly improve the computational efficiency.

Table 3. Comparison of parallel computing performance under different grid cell sizes.

\begin{tabular}{ccccc}
\hline Grid Cell Size & CPU (min) & OpenMP (min) & Time of a Cycle Calculation (ms) & Speedup Ratio \\
\hline $5 \mathrm{~m}$ & 43.07 & 12.16 & 51 & 3.54 \\
$10 \mathrm{~m}$ & 5.53 & 1.71 & 15 & 3.23 \\
$20 \mathrm{~m}$ & 0.65 & 0.29 & 5 & 2.24 \\
$30 \mathrm{~m}$ & 0.23 & 0.10 & 3 & 2.30 \\
\hline
\end{tabular}

\subsection{Real-Time Interactive Analysis}

According to the multiscale parallel optimization experiments, a suitable scale ( $20 \mathrm{~m}$ grid cell size) has been chosen for the numerical simulation of debris flow disasters. The computational efficiency of one simulation step can be completed within $5 \mathrm{~ms}$, and the rendering efficiency is approximately $40 \mathrm{fps}$. The VGE system can support a real-time interactive analysis of debris flow disasters. The disaster information including the risk area, risk residential area, and risk roads under different risk grades can be quickly calculated, as shown in Figure 8 and Table 4.

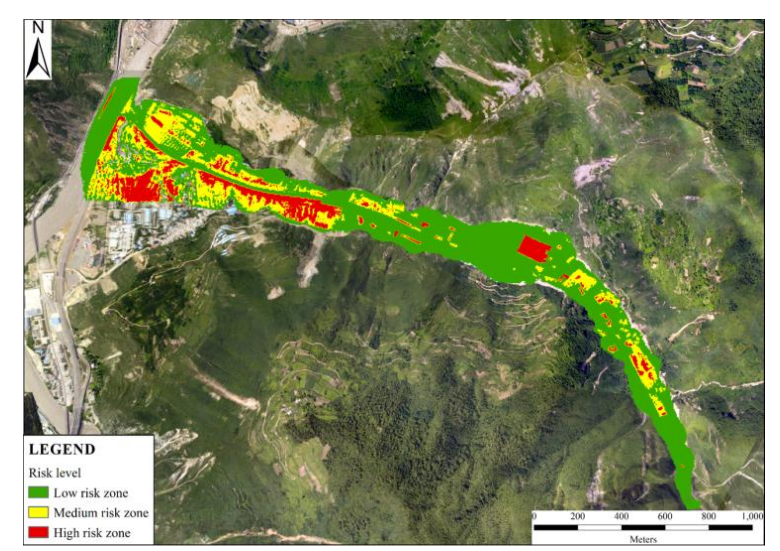

Figure 8. Risk map of the debris flow disaster in Qipan gully. 
Table 4. Statistical results of the risk assessment of the debris flow disaster.

\begin{tabular}{cccc}
\hline Risk Degree & Risk Area & Risk Residential Area & Risk Roads \\
\hline Low risk & $420,000 \mathrm{~m}^{2}$ & $30,500 \mathrm{~m}^{2}$ & $4900 \mathrm{~m}$ \\
Medium risk & $120,000 \mathrm{~m}^{2}$ & $39,400 \mathrm{~m}^{2}$ & $1800 \mathrm{~m}$ \\
High risk & $106,000 \mathrm{~m}^{2}$ & $36,700 \mathrm{~m}^{2}$ & $900 \mathrm{~m}$ \\
\hline
\end{tabular}

Meanwhile, the debris flow routing process, inundated area, and flow depth can be displayed in real time in the virtual geographic scene. Users can visually obtain the risk levels of different disaster areas and the spatial distribution of buildings, roads and other objects with different risk degrees. Users can also query the disaster information such as the inundated area, risk population, and risk roads, as shown in Figure 9. It is convenient for emergency rescuers to obtain decision-making information quickly.

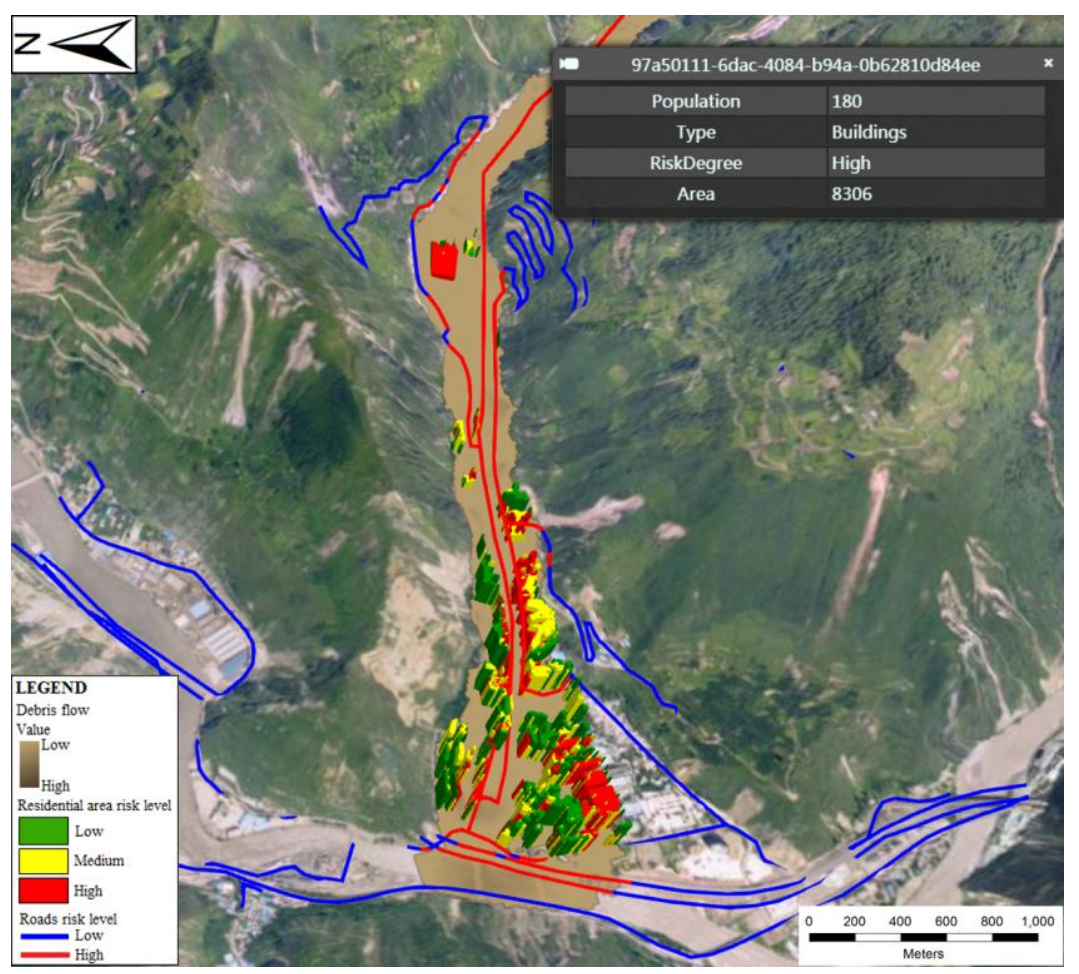

Figure 9. 3D visualization of disaster information.

\section{Conclusions and Future Work}

Analytical GIS is one of the current focuses of geographic information science researches [28,43-45]. A VGE system has been developed to support the rapid risk analysis of debris flow disasters in residential areas. A suitable scale has been chosen to implement the multiscale parallel computing of debris flow disasters. The computational efficiency and visual rendering efficiency have been greatly improved. The risk area, risk residential area, and risk roads under different conditions can be quickly obtained. Thus, this system can support real-time simulation, visualization, and interactive analysis. The main contributions of this paper are summarized as follows:

First, a multiscale parallel optimization method was designed to improve the simulation efficiency of debris flow disasters. The OpenMP framework was used to implement parallel optimization of the debris flow simulation. Several typical grid cell sizes were tested in a sensitivity analysis of the inundated area, maximum flow depths, and maximum flow velocities. The experimental results show that the appropriate grid cell sizes within a range from $10 \mathrm{~m}$ to $20 \mathrm{~m}$ can be used for simulation analysis. 
The computational efficiency of one simulation step can be completed within $15 \mathrm{~ms}$, and the maximum speedup ratio is approximately 148 . Thus, the multiscale parallel optimization can support real-time interactive analysis.

Second, the numerical simulation, risk assessment and 3D visualization of the debris flow disasters were tightly integrated into the VGE system for real-time interactive operation and risk analysis. A quantitative risk assessment method was deigned. 3D visualization based on the WebGL technology was implemented to dynamically display the simulation results on a virtual earth. Users can obtain the inundated area, flow depth, risk area, and spatial distribution of risk objects at different risk levels and query the disaster information in the debris flow disaster routing process, such as the risk population, risk residential area, and risk roads. The average efficiency of visual rendering is approximately $40 \mathrm{fps}$, which can support real-time interactive analysis of debris flow disasters in a virtual geographic scene.

Third, a VGE prototype system was provided to support the emergency risk analysis of debris flow disasters in residential areas. The Qipan gully in Wenchuan County, Sichuan Province, China, was selected as the case area. This system can support the rapid simulation, interactive analysis, and dynamic visualization of the debris flow disaster, which can provide scientific evidence for crowd evacuation, temporary shelter arrangement, and rescue planning in emergency situations. In short, our study provides a new paradigm that will help to promote the application of spatial information technologies to emergency disaster simulations and analyses.

Despite the achievements described above, this paper has shortcomings. First, based on multiscale optimization and parallel computing, the VGE system can support the real-time simulation of debris flow disasters. However, due to the competition between reading and writing in the protocol computing of the debris flow disaster simulation algorithm, complete parallel processing cannot be carried out. According to Amdahl's law, if there is a serial computing in parallel programs, the speedup ratio cannot increase with the increase of computational kernel [46]. Thus, how to optimize the parallel computing algorithm of debris flow disasters should be discussed in the future. Second, several typical grid cell sizes are selected in this paper to determine a proper grid cell size. Other grid subdividing methods will be used to obtain an optimal result. Third, our experimental work in this paper was aimed at the Qipan gully in Wenchuan County, Sichuan Province, China. Thus, if necessary, the framework and method that is presented in this paper will be used for other regions.

Acknowledgments: This paper was supported by the National Key Research and Development Program of China (Grant No. 2016YFC0803105), the National High Technology Research and Development Program of China (Grant No. 2015AA123901), the National Basic Surveying and Mapping Technology Project (Grant No. 2017KJ0303), the Smart Guangzhou Spatio-temporal Information Cloud Platform Construction (Grant No. GZIT2016-A5-147), and the 2015 Cultivation Program for the Excellent Doctoral Dissertation of Southwest Jiaotong University.

Author Contributions: Lingzhi Yin and Jun Zhu provided the initial idea for this study, conceived the experiments, and wrote the paper; Yi Li, Qing Zhu and Hua Qi contributed the experimental data and supplied the infrastructure for the experiments; Lingzhi Yin, Mingwei Liu, Weilian Li and Chao Zeng performed the experiments and analyzed the results; and Zhenyu Cao, Weijun Yang and Pengcheng Zhang provided important suggestions and reviews.

Conflicts of Interest: The authors declare no conflicts of interest.

\section{References}

1. Iverson, R.M.; Reid, M.E.; LaHusen, R.G. Debris-flow mobilization from landslides. Annu. Rev. Earth Planet. Sci. 1997, 25, 85-138. [CrossRef]

2. Borga, M.; Stoffel, M.; Marchi, L.; Marra, F.; Jakob, M. Hydrogeomorphic response to extreme rainfall in headwater systems: Flash floods and debris flows. J. Hydrol. 2014, 518, 194-205. [CrossRef]

3. Hong, H.Y.; Pradhan, B.; Xu, C.; Bui, D.T. Spatial prediction of landslide hazard at the Yihuang area (China) using two-class kernel logistic regression, alternating decision tree and support vector machines. Catena 2015, 133, 266-281. [CrossRef]

4. Hürlimann, M.; Copons, R.; Altimir, J. Detailed debris flow hazard assessment in Andorra: A multidisciplinary approach. Geomorphology 2006, 78, 359-372. [CrossRef] 
5. Aronica, G.T.; Biondi, G.; Brigandì, G.; Cascone, E.; Lanza, S.; Randazzo, G. Assessment and mapping of debris-flow risk in a small catchment in eastern Sicily through integrated numerical simulations and GIS. Phys. Chem. Earth Parts A/B/C 2012, 49, 52-63. [CrossRef]

6. Lin, J.W.; Chen, C.W.; Peng, C.Y. Potential hazard analysis and risk assessment of debris flow by fuzzy modeling. Nat. Hazards 2012, 64, 273-282. [CrossRef]

7. Cui, P.; Xiang, L.Z.; Zou, Q. Risk assessment of highways affected by debris flows in Wenchuan earthquake area. J. Mt. Sci. 2013, 10, 173-189. [CrossRef]

8. Fuchs, S.; Heiss, K.; Hübl, J. Towards an empirical vulnerability function for use in debris flow risk assessment. Nat. Hazards Earth Syst. Sci. 2007, 7, 495-506. [CrossRef]

9. Liu, K.F.; Li, H.C.; Hsu, Y.C. Debris flow hazard assessment with numerical simulation. Nat. Hazards 2009, 49, 137-161. [CrossRef]

10. Hu, K.H.; Wei, F.Q.; He, Y. Application of particle model in risk zoning of debris flows. J. Mt. Sci. 2003, 21, 726-730.

11. Liu, X.; Lei, J. A method for assessing regional debris flow risk: An application in Zhaotong of Yunnan province (SW China). Geomorphology 2003, 52, 181-191. [CrossRef]

12. Pradhan, B. Remote sensing and GIS-based landslide hazard analysis and cross-validation using multivariate logistic regression model on three test areas in Malaysia. Adv. Space Res. 2010, 45, 1244-1256. [CrossRef]

13. Wei, F.Q.; Gao, K.C.; Hu, K.H.; Li, Y.; Gardner, J.S. Relationships between debris flows and earth surface factors in Southwest China. Environ. Geol. 2008, 55, 619-627. [CrossRef]

14. Hu, K.; Wei, F.; Li, Y. Real-time measurement and preliminary analysis of debris-flow impact force at Jiangjia Ravine, China. Earth Surf. Process. Landf. 2011, 36, 1268-1278. [CrossRef]

15. Gentile, F.; Bisantino, T.; Liuzzi, G.T. Debris-flow risk analysis in south Gargano watersheds (Southern-Italy). Nat. Hazards 2008, 44, 1-17. [CrossRef]

16. Calvo, B.; Savi, F. A real-world application of Monte Carlo procedure for debris flow risk assessment. Comput. Geosci. 2009, 35, 967-977. [CrossRef]

17. Wang, C.; Li, S.; Esaki, T. GIS-based two-dimensional numerical simulation of rainfall-induced debris flow. Nat. Hazards Earth Syst. Sci. 2008, 8, 47-58. [CrossRef]

18. Ouyang, C.; He, S.; Tang, C. Numerical analysis of dynamics of debris flow over erodible beds in Wenchuan earthquake-induced area. Eng. Geol. 2015, 194, 62-72. [CrossRef]

19. D'Ambrosio, D.; Spataro, W.; Iovine, G. Parallel genetic algorithms for optimising cellular automata models of natural complex phenomena: An application to debris flows. Comput. Geosci. 2006, 32, 861-875. [CrossRef]

20. Lacasta, A.; Juez, C.; Murillo, J.; Garcia-Navarro, P. An efficient solution for hazardous geophysical flows simulation using GPUs. Comput. Geosci. 2015, 78, 63-72. [CrossRef]

21. Sanders, J.; Kandrot, E. CUDA by Example: An Introduction to General-Purpose GPU Programming; Addison-Wesley Professional: Upper Saddle River, NJ, USA, 2010.

22. Yang, F.K.; Guan, Q.; Zhang, Z.G.; Li, X.T. Debris-flow risky district decision system based on socket distributed-computing. Comput. Eng. Des. 2010, 31, 4909-4912.

23. Yang, S.; Guan, Q. CUDA-based simulation of debris flow. Comput. Eng. Des. 2011, 32, 4231-4236.

24. Spataro, D.; D'Ambrosio, D.; Filippone, G.; Rongo, R.; Spataro, W.; Marocco, D. The new SCIARA-fv3 numerical model and acceleration by GPGPU strategies. Int. J. High Perform. Comput. Appl. 2017, 31, 163-176. [CrossRef]

25. Oliverio, M.; Spataro, W.; D’Ambrosio, D.; Rongo, R.; Spingola, G.; Trunfio, G.A. OpenMP parallelization of the SCIARA Cellular Automata lava flow model: Performance analysis on shared-memory computers. Procedia Comput. Sci. 2011, 4, 271-280. [CrossRef]

26. Amritkar, A.; Tafti, D.; Liu, R.; Kufrin, R.; Chapman, B. OpenMP parallelism for fluid and fluid-particulate systems. Parallel Comput. 2012, 38, 501-517. [CrossRef]

27. Yu, M.; Huang, Y.; Xu, Q.; Guo, P.; Dai, Z.L. Application of virtual earth in 3D terrain modeling to visual analysis of large-scale geological disasters in mountainous areas. Environ. Earth Sci. 2016, 75. [CrossRef]

28. Lin, H.; Chen, M.; Lu, G.N.; Zhu, Q.; Gong, J.H.; You, X.; Wen, Y.N.; Xu, B.L.; Hu, M.Y. Virtual geographic environments (VGEs): A new generation of geographic analysis tool. Earth Sci. Rev. 2013, 126, 74-84. [CrossRef]

29. Chen, M.; Lin, H.; Kolditz, O.; Chen, C. Developing dynamic virtual geographic environments (VGEs) for geographic research. Environ. Earth Sci. 2015, 74, 6975-6980. [CrossRef] 
30. Xu, B.L.; Lin, H.; Chiu, L.S.; Hu, Y.; Zhu, J.; Hu, M.Y.; Cui, W.N. Collaborative virtual geographic environments: A case study of air pollution simulation. Inf. Sci. 2011, 181, 2231-2246. [CrossRef]

31. Zhu, J.; Yin, L.Z.; Wang, J.H.; Zhang, H.; Hu, Y.; Liu, Z.J. Dam-break flood routing simulation and scale effect analysis based on virtual geographic environment. IEEE J. Sel. Top. Appl. Earth Obs. Remote Sens. 2015, 8, 105-113. [CrossRef]

32. Liang, J.M.; Gong, J.H.; Sun, J.; Liu, J. A customizable framework for computing sky view factor from large-scale 3D city models. Energy Build. 2017, 149, 38-44. [CrossRef]

33. Yin, L.Z.; Zhu, J.; Zhang, X.; Li, Y.; Wang, J.H.; Zhang, H.; Yang, X.F. Visual analysis and simulation of dam-break flood spatiotemporal process in a network environment. Environ. Earth Sci. 2015, 74, 7133-7146. [CrossRef]

34. Shao, S.D.; Wang, L.X. Debris flow simulation and hazard zone mapping in mountainous regions of Beijing. J. Beijing For. Univ. 1999, 21, 11-16.

35. Wang, G.Q.; Shao, S.D.; Fei, X.J. Particle model for alluvial fan formation. In Debris-Flow Hazards Mitigation: Mechanics, Prediction, and Assessment; ASCE: Reston, VA, USA, 1997; pp. 143-152.

36. Zou, Q.; Cui, P.; Zeng, C.; Tang, J.X.; Regmi, A.D. Dynamic process-based risk assessment of debris flow on a local scale. Phys. Geogr. 2016, 37, 132-152. [CrossRef]

37. Qiao, C.J.; Li, J.S.; Tian, Z.S. A new approach for fluid dynamics simulation: The Short-lived Water Cuboid Particle model. J. Hydrol. 2016, 540, 437-456. [CrossRef]

38. Jin, H.L.; Gao, J.X. An Algorithm for Real-Time Visualization of Large-Scale Terrain. J. Inst. Surv. Mapp. 2006, 23, 65-68.

39. Liu, G.X.; Dai, E.F.; Wu, S.H.; Wu, W.X. A study on theory and method in debris flow risk assessment. Prog. Geogr. 2012, 31, 383-391.

40. Jiang, L.L.; Qi, Q.W.; Zhang, A. Color on emergency mapping. In Proceedings of the Geoinformatics 2007: Cartographic Theory and Models, Nanjing, China, 25-27 May 2007; SPIE: Bellingham, WA, USA, 2007; Volume 6751, p. 675104.

41. Zhu, J.; Tang, C.; Chang, M.; Le, M.H.; Huang, X. Field Observations of the Disastrous 11 July 2013 Debris Flows in Qipan Gully, Wenchuan Area, Southwestern China. In Engineering Geology for Society and Territory_Volume 2; Springer: Cham, Switzerland, 2015; pp. 531-535.

42. Zeng, C. Vulnerability Assessment of Building to Debris Flow Hazard. Ph.D. Thesis, University of Chinese Academy of Sciences, Chengdu, China, 2014.

43. Longley, P.A.; Batty, M. Spatial Analysis: Modelling in a GIS Environment; John Wiley \& Sons: Hoboken, NJ, USA, 1996.

44. Maguire, D.J.; Batty, M.; Goodchild, M.F. GIS, Spatial Analysis, and Modeling; Esri Press: Redlands, CA, USA, 2005.

45. Lü, G.N. Geographic analysis-oriented Virtual Geographic Environment: Framework, structure and functions. Sci. China Earth Sci. 2011, 54, 733-743. [CrossRef]

46. Wang, Q.J.; Gao, Y.; Li, C.H. Research on Multi-Core-Based Multitask parallel processing Technology. Comput. Appl. Softw. 2012, 29, 141-143.

(C) 2017 by the authors. Licensee MDPI, Basel, Switzerland. This article is an open access article distributed under the terms and conditions of the Creative Commons Attribution (CC BY) license (http:/ / creativecommons.org/licenses/by/4.0/). 